and that in this, as in so much else, the Church has led the way, for Samuel Crowther was himself an African and the work once begun by missionaries from overseas is increasingly being carried out by the men and women of Nigeria themselves.

\title{
East African Institute of Social Research Conference, June I957
}

THE following papers were given at the East African Institute of Social Research's summer conference: Social class in modern Buganda, by L. A. Fallers; The rise of the Uganda African Farmers' Union in Buganda, by A. B. Mukwaya; The report of the Income Tax Commission, by David Walker; Regional disparities of income and taxation in Uganda, by W. Elkan; Some problems of change amongst the Kuria, by M. J. Ruel; A history of relations between the Arusha and the Masai, by P. H. Gulliver; Recent researches amongst the Masai, by Alan H. Jacobs; The structure of Shambalai, by E. V. Winans.

\section{Sierra Leone's first Festival of Arts}

THE festival of arts held in Freetown in December revealed and encouraged the creative talents of the people of Sierra Leone in a wide variety of crafts, ranging from carving, weaving, dyeing, and leatherwork to tribal dancing. Sir Gordon Russell, Director of the Council of Industrial Design, lectured and adjudicated in some of the competitions. During the festival Sierra Leone's Museum was officially opened. Among its exhibits are the crown of Paramount Chief Jaia Kaikai I, a statute of Madame Yoko (Paramount ruler of the Kpa Mende from 188 , to 1906), and the original Royal Charter of 1799 which gave Freetown its mayor.

\section{Lamu and the East African Dhow Traffic}

DR. A. H. J. PrINs, Reader in Cultural Anthropology in the State University of Groningen, Netherlands, has just completed a six months' study of the social and economic organization of the East African dhow trade and its implications for the population of the Lamu Islands off the coast of northern Kenya. This is the first modern analysis of one of the Islamic coastal communities, the study of which was judged to be urgent and long overdue in a recent assessment of current and necessary research in East Africa (see Africa, xxvi. 3, 1956, pp. 271, 275). Before embarking on this study in May, Dr. Prins also had an opportunity to visit the Persian Gulf area, with which the African coast is most intimately connected by the seasonal traffic of the ocean-going dhows. Part of the results of the present field study will be incorporated in his forthcoming section on the Swahili, which is to appear in the Institute's Ethnographic Survey series. The Lamu study, together with Professor Grottanelli's researches among the Northern Bajun, also an important component of the population of the Lamu area, means that up-to-date material on the northern part of the coastal civilization will now be available. Moreover, Dr. P. Lienhardt is at present engaged in field research among the Arabs of Zanzibar, and Dr. G. Wilson, the Kenya Government sociologist, has completed his social survey of Mombasa town. It may therefore be expected that our knowledge of an African culture area so long neglected will shortly be enlarged to a very considerable extent.

[Communicated by Dr. A. H. J. Prins]

Researches at I.R.S.A.C.

A stuDY of the history of Ruanda and Urundi is being undertaken by M. Jan Vansina in co-operation with M. l'Abbé Kagame. M. A. A. Trouwborst, who is due to arrive at I.R.S.A.C. in January, is to study the political structure of Urundi, with special reference to 
the relationship between the local governments and the central administration. Dr. Jacques Maquet hopes to undertake a study of the Yeke of Katanga in the near future.

\section{Education of the African Child}

ON the initiative of the Bureau International Catholique d'Enfance, a conference was held at Yaounde (French Cameroons) in January 1957. A questionnaire had been prepared in advance of the conference, and an analysis of the replies received, together with an account of the work of the five sections of the conference and of the conclusions arrived at, are given in C.E.P.S.I., June 1957. These include the importance of carrying out an intensive psychological and sociological study of the African child and his background; existing research centres for this purpose should be further developed and their numbers increased. More teachers are needed and particular efforts should be made to ensure that parents realize their responsibilities and play their own part in the education of their children. It is important that those in charge of education should have a sound religious background which can be communicated to the children. Stress was also laid on the need for raising the standard of living, especially in rural areas, and on the improvement of the status of women; care should be taken to educate young women to fulfil the roles of wives and mothers. The task of educating the African child is one which calls for the collaboration of all.

\section{The Press in Africa}

The Press in Africa, edited by Helen A. Kitchen, is the first volume in a series of handbooks which Ruth Sloan Associates proposes to publish. It contains a preface by Ruth Sloan and an introduction, 'A Nigerian journalist looks at African newspapers', by Abiodan Aloba, and separate chapters on each of twenty-three territories. It is hoped that the second volume, $A$ Survey of American Interests in Africa, will be ready for publication in March or April I958. The third volume will be a Survey of Educational Policies and Practices in Africa.

\section{Centre Intercontinental d'Etudes de Techniques Biologiques, Paris}

LEs correspondants du C.I.É.T.B. en Afrique sont groupés selon les subdivisions en aires subcontinentales, divisées à leur tour en régions naturelles. Celles-ci sont partagées en sections correspondant généralement à un territoire administratif (État ou pays sous tutelle). A l'intérieur du C.I.É.T.B., l'Unité Afrique coopère à ses problèmes de chaque échelon, avec d'autres aires subcontinentales intertropicales (américaine, asiatique, pacifique), et avec des organismes internationaux, nationaux ou régionaux par le canal du Secrétariat Général. Le Comité Afrique est formé des Délégués des trois aires subcontinentales, A. Dziri (Tunis), J. Pagot (Bamako), J. M. Watt (Johannesburg), assistés des délégués régionaux.

Les buts généraux de la Section Anthropologique sont de coordonner les rapports entre ses deux sous-sections (Ethnologique et Anthropobiologique) au sein du C.I.É.T.B., avec les autres sections, soit par le Secrétariat Général, soit sous forme de commissions; coordonner les rapports entre spécialistes correspondant à la même discipline intéressée; poursuivre des travaux et enquêtes scientifiques et technologiques sous couvert du Secrétariat Général avec les organismes internationaux. La sous-section ethnologique a pour but d'étudier les caractères ethniques naturels des divers peuplements humains. Elle est en rapport constant avec le Bureau Géographique pour l'étude des domaines continentaux, régionaux, etc. de chaque ethnie. La sous-section anthropobiologique a pour but d'étudier par travaux de ses membres et par enquêtes auprès des autres sections du C.I.É.T.B. (Naturaliste, Sciences médicales) la Biologie normale de l'homme et des anthropoïdes, de déterminer les biotypes non-ethniques, les règles de la climatérie humaine. 